Educational Philosophy versus Teaching Styles

\title{
Relationship between Educational Philosophy and Teaching Styles of Nursing Educators
}

\author{
Abeer Mohamed Abd Elkader, lecturer \\ Nursing Education, Faculty of Nursing, El-Minia University
}

\begin{abstract}
Background: Educational philosophies and teaching styles are two aspects of adult learning that influence the teaching-learning transaction in colleges and universities. The educational philosophy can inform the educator with strategies and methods for implementing adult learning principles. The study of teaching style is important because it assists educators in designing a positive learning experience for students. Objective: This study aims to identify the relationship between the educational philosophies and teaching styles among nursing educators at El-Minia Faculty of Nursing. Setting: The study was carried out at at El-Minia Faculty of Nursing. Subjects: The study subjects included a total number of 70 nursing educators. Tools: Tools used in the study were the Educational philosophy and Teaching style questionnaires. Results: The study results indicated that the dominant educational philosophies among educators were humanistic and radical education philosophy. Also, the dominant teaching styles were expert and facilitator. Recommendations: It was recommended to conduct a study to investigate the quality of nursing education services provided at the national level and compare the results to student achievement, teaching style, or educational philosophy.
\end{abstract}

Keywords: Educational philosophy, Teaching Style, Nursing Education.

\section{Introduction}

Educational philosophy and teaching styles are two aspects of adult learning that influence the teaching-learning transaction in colleges and universities. The educational philosophy can inform the educator with strategies and methods for implementing adult learning principles. Floyd (2010) described the importance of educators knowing their educational philosophy because selfexamination and critical inspection of practices will create a consciousness of some unconscious beliefs that affect teaching $\operatorname{practice}^{(1,2)}$. 
Educational Philosophy versus Teaching Styles

The literature on educational philosophy explains, "When an adult educator engages in the practice of education, certain beliefs about life in general are applied to the practice". Therefore, educators hold beliefs about how adults learn, how they should be taught, and what instructional practice should look like. Furthermore, a basic assumption underlying the teaching/learning process is that the purpose of education is to promote, guide, and/or facilitate some sort of change in individuals. These assumptions of education, the role of the adult educator and students, and the understanding of differences among learners are all components of an educational philosophy ${ }^{(1,3)}$.

Educators should consider implications of what they are doing in their classrooms before interacting with students. Unfortunately, few educators consider the implications of their methods or activities. Anyone who engages in the act of teaching is guided by some theory or some philosophy. Moreover, Educational philosophy can provide the educator with an attitude that requires all of the pieces in the educational situation to be considered. Therefore, the educator becomes a philosopher of education when consideration and application of principles occur in classroom processes. Educational philosophies affect educators, curriculum, and learning materials, therefore, it is vital for educators to "engage in a process of examining what they believe and value so that educators will have a clearer sense of where the instruction and learning journey is leading, ${ }^{,(1,3)}$.

Each philosophy illustrates the role of the educator and student. The five educational philosophies are: liberal, behavioral, progressive, humanistic and radical. According to descriptions of the philosophies written by Floyd (2010), the humanistic and radical philosophies incorporated learner-centered styles. The remaining three philosophies named behavioral, liberal, progressive tend to be more teacher-centered styles ${ }^{(1,4)}$.

Liberal education philosophy emphasizes learning for the sake of learning. Classical humanism, comprehensive education, and traditional knowledge are stressed in the broadest sense. To date, many liberal educators still disregard the sciences as a component of a classical liberal education. There are many things liberal educators feel that can best be taught directly by the educator. The lecture method, if well organized and suited to the ability of the students, is recognized as an efficient instructional strategy. Learning through projects, insight, or discovery methods de-emphasize the directive role of the educator and are not endorsed by liberal educators. The purpose of Liberal Adult Education is to: develop intellectual powers of the mind; to make a person literate in the broadest sense intellectually, morally, spiritually, and aesthetically. In this philosophy the educator serves as the expert, the transmitter of 
knowledge, the authority who clearly directs the learning process ${ }^{(5)}$.

Behavioral education philosophy believes the essential goal of education is to reinforce cooperation and interdependence for the good of the collective and the global society. It also believe it is the educator's responsibility to create environments that prompt and reinforce behaviors, in order eliminate undesirable behaviors and meet the goal of survival for mankind. In the behaviorist framework, the educator and learner roles are precisely defined. Behaviorism in adult education emphasizes such concepts as control, behavioral modification, learning through reinforcement and management by objectives. Behavioral objectives specify the conditions of stimuli, the behavior to be performed, and the criteria by which the behavior will be judged. Many areas of education utilize Behaviorism for instructional planning to measure the overt activity of the learner ${ }^{(6)}$.

Progressive education philosophy promotes well-being and effectiveness within society by taking into account the relationships between society and education. The desires and understanding of the learner are at the core of the progressive education movement. Learners ascertain problems and identify solutions in order to enhance their aptitude through experience based education and skills acquisition. In progressive education, programs are focused on learners, and should be adjusted continually in order to address the specific needs and circumstances adults face. Progressive educators, to ascertain important truths about the student's environment, use a mixture of experimental and scientific techniques. The purpose of Progressive Adult Education is to: promote societal well-being; enhance individual effectiveness in society; and to give learners practical knowledge and problem solving skills. The educator's role is to be an organizer, to stimulate, to investigate and to evaluate the learning process ${ }^{(5)}$.

Humanistic education philosophy conceptualizes learning in terms of freedom and autonomy, cooperation and participation. Under the humanistic philosophy, the educator is a facilitator or learning partner and respects the self-directed nature of the student. Educators create learning opportunities and promoting learning without dictating the behavior or activities by valuing and incorporating the life experiences of the learner into the classroom. Humanistic educators use pass-fail grading system, and students evaluate themselves with self-reporting tools. Fundamentally in the humanistic philosophy, "the emphasis is upon learning rather than teaching and the student rather that the educator" .The purpose of Humanistic Adult Education is to: enhance personal growth and development, and to facilitate self-actualization. The educator serves as a facilitator, helper, and partner who promotes but does not direct learning ${ }^{(5)}$. 
Educational Philosophy versus Teaching Styles

Radical education philosophy seeks to increase personally awareness that knowledge is power and radical change in society and history can only be achieved through their education. In the radical philosophy, educators are removed from positions of power and control over the learning environment. Educators become liberators who suggest but do not determine the direction of learning and students assist educators with curriculum design. Class work focuses on dialogue and the exchange of ideas with total participation from course participants. Discussions are based on personal exposure to real life situations and societal problems, and students utilize critical reflection and problem-posing techniques to identify possible solutions as a group. The purpose of Radical Adult Education is to: bring about through education fundamental social, political, and economic changes in society. The educator serves as a coordinator who suggests but does not determine direction for learning and there is equality between educator and learner ${ }^{(6)}$.

Educational philosophy also impacts the teaching style of the educator. Teaching styles are composed of the individual traits the educator possesses and exhibit despite of the content or curriculum. Many educators prefer one style to the other, while they may practice behaviors of both. Research continues to investigate the impact different teaching styles have in various learning environments. Many adult learners require more time and energy to master what is taught; therefore, the educator's duty remains in improving curriculum delivery to meet individual learner needs ${ }^{(7)}$.

Most educators agreed that quality of teaching contributes to quality of learning. In order to help college or higher institution students to learn effectively educators need to know and use different styles of teaching. Teaching style is defined as "the distinct qualities displayed by the educator that are persistent from situation to situation regardless of the content" ${ }^{(2,8)}$.

The five primary teaching styles described are expert, formal authority, personal model, facilitator, and delegator. Expert teaching style possesses knowledge and expertise that students need. Strives to maintain status as an expert among students by displaying detailed knowledge and by challenging students to enhance their competence. Concerned with transmitting information and insuring that students are well prepared $^{(9)}$. Furthermore, formal authority teaching style possesses status among students because of knowledge and role as a faculty member. Concerned with providing positive and negative feedback, establishing learning goals, expectations, and rules of conduct for students. Concerned with the correct, acceptable, and standard ways to do things and with providing students with the structure they need to learn. Moreover, personal model teaching style believes in "teaching by personal example" and 
establishes a prototype for how to think and behave, oversees, guides, and directs by showing how to do things, and encouraging students to observe and then to emulate the educator's approach. ${ }^{(10)}$

Facilitator teaching style emphasizes the personal nature of educator-student interactions. Guides and directs students by asking questions, exploring options, suggesting alternatives, and encouraging them to develop criteria to make informed choices. Overall goal is to develop in students the capacity for independent action, initiative, and responsibility. Works with students on projects in a consultative fashion and tries to provide as much support and encouragement as possible. Delegator teaching style concerned with developing students' capacity to function in an autonomous fashion. Students work independently on projects or as part of autonomous teams. The educator is available at the request of students as a resource person ${ }^{(9)}$.

Teachers can be aware of their teaching practice by consistently examining the why, what, and how of their educational habits. The study of teaching style is important because it assists adult educators in designing a positive learning experience for students. Moreover, knowledge of adult education theories and practices enables the professors to better serve the student population that they teach. Adult educators are then faced with the task of teaching in a manner that addresses the individual and collective needs of their students. To begin the process of teaching, adult educators should seek to have an understanding of their individual beliefs and values about education. Galbraith (2004) stated that awareness of one's beliefs, values, and attitudes about educational philosophy provide a strong foundation for teaching adults. This foundation places the adult educator in a position to meet the needs of their learners. In addition, one's education philosophy can serve as the catalyst for analyzing one's teaching style ${ }^{(10)}$.

Moreover, the purpose of an educational philosophy, for those who have one, is to help educators recognize the need to think and see more clearly what they are doing in the larger context of individual and social development. It should be noted that many educators do not have any identified philosophy ${ }^{(11)}$. Furthermore, research suggests a direct relationship between educational philosophies and educator teaching style. The educator's actual conception of philosophy will affect his mode of teaching ${ }^{(12)}$. Also, teaching philosophies are a basis for educational practices in the teaching-learning transaction. Educator's belief system serves as a basis for curriculum development, evaluation processes, and interacting with students ${ }^{(13)}$.

The significant of the present study is to foster quality of teaching and learning by overcome the occurrence of unproductive delivery methods of teaching by educators and low performance by the undergraduates. The results of this study could be used to help 
nursing educators identify their teachingstyles, personal educational philosophies, and the impact those philosophies and styles have upon teaching-learning process. It is believed that having an awareness of the educational philosophy may lead to more effective teaching and improved learner outcomes such as academic success, goals and mission of the academic organization. Additionally, it is significant for future research and practice in nursing education. A wide body of research revealed the importance of understanding the link between the educator's educational philosophy and their teaching practice. Also, unavailability of previous research conducted on educational philosophies and teaching styles on the national level.

\section{Aim of the Study}

This study was conducted to examine the relationship between educational philosophies and teaching styles of nursing educators at El-Minia Faculty of Nursing.

\section{Materials and Method}

\section{Materials}

Design: A descriptive-correlational research design was utilized in this study.

Setting: This study was conducted at El-ElMinia Faculty of Nursing.

Subjects: The study subjects consisted of nursing educators who were available at the study time in El-El-Minia Faculty of Nursing $(\mathrm{N}=70)$. They were as followed 15 demonstrators holding Baccalaureate degree, 30 assistant lecturer holding Master degree, and 25 lecturers holding Doctorate degree in El-ElMinia Faculty of Nursing.

\section{Tools:}

\section{Tool I:}

a-Demographic data such as age, gender, academic qualification, and years of experience

b-The teaching style questionnaire developed by Grasha (2006) was used for data collection $^{(13)}$. This questionnaire included 40 items which cover five types of teaching styles. The expert ( 8 items), the formal authority ( 8 items), the personal model ( 8 items), the facilitator ( 8 items), and the delegator (8 items) type. Five point Likert scale was used for the participants responses, it ranged from strongly disagree (1) to strongly agree (5). A total score was calculated by summing up the scores of each item. A score range of 1-13 indicated low agreement with teaching style, a score range of 14-27 indicated moderate agreement with teaching style, and a score range of 28-40 indicated high agreement with teaching style.

\section{Tool II: Educational Philosophy}

Questionnaire

An educational philosophy questionnaire developed by West (2008) was used for data collection ${ }^{(14)}$. This questionnaire is 
Educational Philosophy versus Teaching Styles

composed of 75 items which cover five types of educational philosophies. Liberal (15 items), Behavioral (15 items), Progressive (15 items), Humanistic (15 items) and Radical (15 items).A 5-point Likert scale was used for the participants responses. It ranged from strongly disagree (1) to strongly agree (5). A total score was calculated by summing up the scores of each item. A score range of 1-25 indicated low agreement with educational philosophy, a score range of 26-51 indicated moderate agreement with educational philosophy, and a score range of 52-75 indicated high agreement with the educational philosophy.

\section{Method}

1- Permission to conduct the study was obtained from all responsible authorities of El-El-Minia faculty of nursing after explanation the purpose of the study.

2- Permission was obtained from all participants of the study after explanation of the study purpose.

3- The validity of the tool was tested by a jury of five experts in the related field namely nursing education (2 experts[ Alexandria faculty of nursing]) and teaching methods department ( 3 experts[ElEl-Minia faculty of education])

4- The reliability coefficients were Cronbach's alpha $=.99$ for both tools
5- A pilot study was carried out on a sample of $(5 \%)$ from participants to check and ensure the clarity and applicability of the tools. Based on the findings corrections were done.

6- Educational philosophy and Teaching style questionnaire was administered individually to each nursing educator in the study setting. Data were collected over three month's period from $1^{\text {st }}$ November to $30^{\text {th }}$ January for the academic year 2012-2013.

7- All data obtained from all subjects of the study were confidential and used only for the research purposes.

\section{Ethical considerations:}

Permission was obtained from all participants of the study after explanation of the study purpose and confidentiality of data was ensured.

\section{Statistical Analysis}

- The data from the participants were entered and analyzed using statistical package for the social sciences software (SPSS) for windows ( version 20).

- Descriptive statistic e.g. frequency, percentage, mean, standard deviation were calculated.

- ANOVA and T-test were used to determine the level of significance for differences 
Educational Philosophy versus Teaching Styles

among means and to determine the relationship.

- A P value of $\leq 0.05$ was used to assess the significance of the results.

\section{Results}

Table (1) illustrates the distribution of the study subjects according to their general characteristics. It was noticed that, the mean and standard deviation of age were 32.7 and 4.8 respectively. The majority (91.4\%) of the study subjects were female. The highest percent $(42.9 \%)$ of the subjects have master degree. In addition, the highest percent (38 .6\%) of the study subjects have from 5 to 10 years of experience.

Table (2) demonstrates distribution of educational philosophies by the study subjects. It was observed that moderate scores were represented by both humanistic and radical educational philosophies $(55.7 \%)$. Also the same table shows that low scores were represented by educational philosophies named behavioral, progressive, and liberal $(57.1 \%, 48.6 \%$, $48.6 \%$ ) respectively.

Table (3) represents One- way ANOVA of educational philosophies by years of experience. It was a statistical significant relationship between behavioral educational philosophy and years of experience less than 5 years. Where mean score was 35.57 and $\mathrm{P}$ value was 0.02 .

Table (4) shows One- way ANOVA of educational philosophies by academic qualification of the study subjects. No statistical significant difference between educational philosophies and academic qualification of the study subjects was observed. Where $\mathrm{p}$ was 0.276 with liberal, 0.840 with behavioral, 0.157 with progressive, 0.778 with humanistic and 0.433 with radical philosophy.

The data in table (5) indicated distribution of teaching styles by the study subjects. It was noticed that the highest scores represented with expert, facilitator, and Personal model teaching style $(72.9 \%, 68.6 \%$, and $64.3 \%$ ) respectively.

Table (6) illustrates one- way ANOVA of teaching styles by years of experience of the study subjects. There were highly statistical significant differences between years of experience and teaching styles named Expert, Formal authority, and Facilitator $(\mathrm{P}=0.005$, 0.001, and 0.006) respectively.

Table (7) demonstrates one-way ANOVA of teaching styles by academic qualification of the study subjects. A statistical significant relationship between Master degree qualification and both expert and delegator teaching styles was observed $(\mathrm{P}=0.02)$.

Table (8) shows the relationship between educational philosophies and teaching styles of the study subjects. It was noticed that there were positive strong relationship between educational philosophies named liberal, 
behavioral, progressive, and radical with both expert and facilitator teaching style $(\mathrm{P}=0.001,0.008,0.005$, and 0.005) respectively.

\section{Discussion}

An educational philosophy is crucial in the classroom because it serves as the foundation for an educator's teaching style. West (2008) states that the educational philosophy provides an organizing vision for educator's efforts; gives a sense of stability and direction; reduces the feelings of uncertainty; provides a sense of collective professional identity that leads to professional strength among educators ${ }^{(14)}$.

The findings of this study revealed that the study subjects tended to have neutral educational philosophy and therefore were not likely to have extreme agreement or disagreement with the certain educational philosophy. Also, the most dominant educational philosophies among educators were Humanistic and Radical. The humanistic and radical philosophies incorporated learner-centered styles. So, fundamentally in the humanistic philosophy, "the emphasis is upon learning rather than teaching and the student rather than the educator. Moreover, the humanistic education philosophy can fully support the function of the learner-centered instructional model, because "the role of the educator in a humanistic education setting is that of a facilitator, helper, and partner in ASNJ Vol.16 No. 1, 2014 the learning process"(15). In learner-centered instruction, the educator is more of a facilitator rather than a lecturer. Moreover, learnercentered instruction allows students to be proactive, and empowers them to determine the direction of the course. Additionally, a learnercentered educator directs and assists students in gaining their own knowledge rather than learning from lectures ${ }^{(16)}$.

Moreover, this finding agrees with a study conducted by Elias \& Merriam (2005). He revealed that the Radical philosophy is tied for the highest preference among educators. Professors who prefer the radical have a belief system that informs them to serve as a coordinator that makes suggestions to the students' about their learning. However, their actions indicate that they are more of a manager or expert that controls the learning environment. It is possible for educators to have two philosophies with high scores, because of overlap among the philosophies ${ }^{(17)}$.

On the other hand, this finding contradict with Floyd (2010) and Willson (2006) . They reported that the educators preferred the progressive philosophy followed by the behavioral philosophy ${ }^{(1,18)}$.

Furthermore, the study results indicated that the dominant teaching styles were expert and facilitator. Students who are taught by expert educators exhibit an understanding of the concepts targeted in instruction that is more integrated, more coherent and at a higher level of abstraction than understanding achieved by other students. There were five major 
distinctions of expert educators; 1) they can identify essential representations of their subject, 2) guide learning through classroom interactions, 3) monitor learning and provide feedback, 4) attend to emotional attributes, and 5) influence student outcomes ${ }^{(18)}$.

Moreover, a facilitator is an instructor who leads the class in discussions based on the material covered. This is a studentcentered approach. Facilitators rarely lecture; instead, they lead the class to discuss the material and share personal insights from real-world examples ${ }^{(14)}$. This approach allows students to apply the information to their own situations, making the learning more meaningful to them. So, both expert and facilitator style is congruent with methods of instruction that used in nursing program in Minia Faculty of Nursing where students required to utilize nursing care plan, topic presentation, providing patient care under instructor supervision, and demonstration of nursing skills of different specialties. Additionally, this results is supported by Amir \& Jelas (2010) who indicated that expert and facilitator teaching styles were dominant among educators ${ }^{(19)}$.

Furthermore, findings of the present study show positive relationship between Behavioral educational philosophy and years of experience less than 5 year. Students benefit from classrooms where behavioral educational philosophy is used to promote positive behaviors and encourage learning. Benefits include: a) the opportunity to learn, practice and develop social skills ,b) the positive experience of getting along with teachers and other students, c) experiences with group and cooperative activities, d)meeting the goal of following procedures developed for effective learning, and e) learning behavioral expectations in different situations. Corrective feedback on behavior allows students to practice behaviors with guidance from an adult. On the other hand, this finding disagrees with West (2008) results, he reported no significant differences between philosophical preferences and the number of teaching years ${ }^{(14)}$.

Moreover, this study also revealed no statistically significant difference between educational philosophy and academic qualification of the study subjects. This finding supported by West (2008), he expressed that there are lack of interest regarding educational philosophy in educational practice. ${ }^{(14)}$ Otherwise, this finding contradicts with those of Galbraith (2004) results. He stated that Education has a significant focus to transmit change and understanding of educational philosophy provides vision for practice, and a foundation for critically thinking about practice, ideas and the political and social structure ${ }^{(12)}$.

Also, the present study demonstrated that there were positive strong relationship between years of experience and teaching styles named Expert, Formal authority, and Facilitator. This finding is supported by Zhang (2007) results. ${ }^{(16)}$ $\mathrm{He}$ found that older educators were more 
conservative in their teaching styles than were younger educators. Also, less experienced educators tended to report more frequently the use of creative teaching styles than did educators with more teaching experience. On the other hand, this finding contradict with Kulinna (2003), he reported that it was somewhat surprising to find not significantly influence of the teachers' experience and the teaching styles. Also, he mentioned that it might be possible that teachers are not being adequately prepared to address the developmental needs of learners at different age levels ${ }^{(20)}$.

Moreover, the study results indicated that there were positive relationship between Master degree qualification and both expert and delegator teaching style. This finding agrees with Zhang (2007) results $^{(16)}$. He revealed that educational level of educators' played a significant role in their teaching styles. Moreover, educators who had received higher levels of education were significantly more creative in their teaching than were educators who had reported lower levels of education ${ }^{(21,22)}$. Educators with more education be more confident in themselves and conducting their educational practices creatively, they have more resources to draw upon. ${ }^{(23)}$ On the contrary, those with less education may be less confident in themselves and may have fewer resources upon which they could draw ${ }^{(24,25)}$. Otherwise, This finding disagree with O'Brien (2001) who showed no relationship with teaching styles and education level $^{(26)}$.

Moreover, the study results demonstrated that there were positive strong relationship between educational philosophies named liberal, behavioral, progressive, and radical with both expert and facilitator teaching style. This finding in accordance with Suissa (2008) who suggests a direct relationship between educational philosophies and educator teaching style $^{(3)}$. Moreover, In the Progressive, Humanistic, and Radical philosophies the educator serves as an organizer, facilitator, or coordinator. These educational philosophies correlate with learner-centered characteristics; therefore one would expect these philosophies to have a significant relationship with the learner-centered teaching style. Also, there is evidence indicating a relationship between an individual's beliefs, values, or attitudes and the decisions and actions, or more accurately, between what one believes and what one actually does $^{(1,5)}$.

It is believed that having an awareness of one's educational philosophy may lead to more effective teaching and improved learner outcomes such as academic success, goals and mission of the organization and can stimulate reflective thinking. Educators should consider implications of what they are doing in their classrooms before interacting with students. Unfortunately, few educators consider the implications of their methods or activities ${ }^{(1)}$.

Educators are not always aware of their educational philosophy. several reasons may be 
Educational Philosophy versus Teaching Styles

attributed to explaining the educators' lack of awareness or knowledge of their own educational philosophy including: not being asked if they have a philosophy, not being required to have a philosophy, not being provided courses or strategies for comprehending the theoretical underpinnings of philosophy, and they have never been asked to reflect upon their own teaching ${ }^{(6)}$.

\section{Conclusion}

- Educational philosophies of the study participants tended to score at the middle end of the scale.

- Teaching styles of the study participants tended to score at the highest or middle end of the scale.

- Dominant educational philosophies among the study participants were humanistic and radical.

- Dominant teaching style among the study participants were expert and facilitator teaching style

- Findings of this study revealed consistency and positive strong relationship between the educational philosophy (beliefs) and teaching styles (actions) of the nursing educators.

\section{Recommendations}

\section{A- For educators:}

- Encourage educators to examine their personal educational philosophy and teaching styles.

- Enhance educators' awareness through philosophy based teaching workshops

- Provide workshops for educational philosophy and teaching style orientation.

\section{B- For future research:}

- Repeat the present study in different nursing colleges to compare and generalize results.

- Conduct a study to investigate the quality of nursing education services provided at the national level and compare the results to student achievement, teaching style, or educational philosophy.

- Conduct a study to examine teaching styles and students' motivation to learn. 
Educational Philosophy versus Teaching Styles

Table (1): Distribution of the Study Subjects According to their General Characteristics. N=70

\begin{tabular}{||c|c|c||}
\hline \multicolumn{1}{|c|}{ General Characteristic } & No & $\%$ \\
\hline 1- Age: & \multicolumn{2}{|c||}{$32.7+4.8$} \\
\hline 2- Gender : $\quad$ Male & 6 & 8.6 \\
Female & 64 & 91.4 \\
\hline Total & 70 & 100 \\
\hline 3-Academic qualification & & \\
& 15 & 21.4 \\
Baccalaureate degree & 30 & 42.9 \\
Master degree & 25 & 35.7 \\
Doctorate degree & & \\
\hline Total & 70 & 100 \\
\hline 4-Years of experience: & 21 & 30 \\
Less than 5 years & 27 & 38.6 \\
From 5-10 years & 22 & 31.4 \\
More than 10 years & & \\
\hline Total & 70 & 100 \\
\hline \hline
\end{tabular}

Table (2): Distribution of Educational Philosophies by the Study Subjects (N=70)

\begin{tabular}{|c|c|c|c|c|c|c|c|c|c|c|}
\hline \multirow{3}{*}{ Scores } & \multicolumn{10}{|c|}{ Educational Philosophies } \\
\hline & \multicolumn{2}{|c|}{ Liberal } & \multicolumn{2}{|c|}{ Behavioral } & \multicolumn{2}{|c|}{ Progressive } & \multicolumn{2}{|c|}{ Humanistic } & \multicolumn{2}{|c|}{ Radical } \\
\hline & No & $\%$ & No & $\%$ & No & $\%$ & No & $\%$ & No & $\%$ \\
\hline $\begin{array}{c}\text { Low } \\
(1-25)\end{array}$ & 34 & 48.6 & 40 & 57.1 & 34 & 48.6 & 25 & 35.7 & 28 & 40 \\
\hline $\begin{array}{l}\text { Moderate } \\
(26-51)\end{array}$ & 30 & 42.9 & 24 & 34.3 & 30 & 42.9 & 39 & 55.7 & 39 & 55.7 \\
\hline $\begin{array}{c}\text { High } \\
(52-75)\end{array}$ & 6 & 8.6 & 6 & 8.6 & 6 & 8.6 & 6 & 8.6 & 3 & 4.3 \\
\hline $\mathrm{X} \pm$ S.D & \multicolumn{2}{|c|}{$33.686 \pm 12.866$} & \multicolumn{2}{|c|}{$32.143 \pm 14.472$} & \multicolumn{2}{|c|}{$33.357 \pm 14.769$} & \multicolumn{2}{|c|}{$35.043 \pm 13.457$} & \multicolumn{2}{|c|}{$34.471 \pm 13.756$} \\
\hline
\end{tabular}


Educational Philosophy versus Teaching Styles

Table (3): One- way ANOVA of Educational Philosophies by Years of Experience of the Study Subjects $(\mathbf{N}=70)$

\begin{tabular}{|c|c|c|c|c|}
\hline \multirow{3}{*}{$\begin{array}{l}\text { Educational } \\
\text { Philosophy }\end{array}$} & \multicolumn{3}{|c|}{$\begin{array}{ll}\text { Years of Experience } \\
\end{array}$} & \multirow{3}{*}{$\begin{array}{c}\mathbf{P} \\
\text { value }\end{array}$} \\
\hline & Less than 5 years & $5-10$ years & $\begin{array}{c}\text { More than } 10 \\
\text { years }\end{array}$ & \\
\hline & X \pm S.D & X \pm S.D & $X \pm$ S.D & \\
\hline Liberal & $35.857 \pm 15.448$ & $35.556 \pm 13.924$ & $29.3182 \pm 6.883$ & $\begin{array}{c}0.158 \\
\text { NS }\end{array}$ \\
\hline Behavioral & $35.571 \pm 16.907$ & $35.222 \pm 15.363$ & $25.090 \pm 6.900$ & $0.02 *$ \\
\hline Progressive & $34.423 \pm 17.466$ & $36.667 \pm 16.354$ & $28.273 \pm 7.265$ & $\begin{array}{c}0.130 \\
\text { NS }\end{array}$ \\
\hline Humanistic & $36.857 \pm 15.698$ & $34.444 \pm 15.366$ & $34.045 \pm 7.949$ & $\begin{array}{c}0.763 \\
\text { NS }\end{array}$ \\
\hline Radical & $35.714 \pm 14.694$ & $36.667 \pm 16.105$ & $30.591 \pm 8.447$ & $\begin{array}{c}0.275 \\
\text { NS }\end{array}$ \\
\hline
\end{tabular}

Table (4): One-way ANOVA of Educational Philosophies by Academic Qualification of the Study Subjects. $\mathbf{N}=\mathbf{7 0}$

\begin{tabular}{||c|c|c|c|c||}
\hline \hline \multirow{2}{*}{$\begin{array}{c}\text { Educational } \\
\text { Philosophy }\end{array}$} & \multicolumn{3}{|c|}{ Academic Qualification } & \multirow{2}{*}{$\begin{array}{c}\text { P } \\
\text { value }\end{array}$} \\
\cline { 2 - 5 } & Baccalaureate & Master & Doctorate & \\
\hline Liberal & $32.200 \pm 6.527$ & $34.600 \pm 15.080$ & $33.480 \pm 13.181$ & 0.276 \\
\hline Behavioral & $27.800 \pm 7.504$ & $35.000 \pm 15.835$ & $31.320 \pm 15.606$ & 0.840 \\
\hline Progressive & $27.400 \pm 7.980$ & $36.400 \pm 16.664$ & $33.280 \pm 14.856$ & 0.157 \\
\hline Humanistic & $33.800 \pm 8.670$ & $34.400 \pm 15.843$ & $36.560 \pm 13.023$ & 0.778 \\
\hline Radical & $31.000 \pm 6.106$ & $36.600 \pm 17.057$ & $34.000 \pm 12.539$ & 0.433 \\
\hline
\end{tabular}


Educational Philosophy versus Teaching Styles

Table (5): Distribution of Teaching styles by the Study Subjects (N=70)

\begin{tabular}{|c|c|c|c|c|c|c|c|c|c|c|}
\hline \multirow{3}{*}{ Scores } & \multicolumn{10}{|c|}{ Teaching Styles } \\
\hline & \multicolumn{2}{|c|}{ Expert } & \multicolumn{2}{|c|}{$\begin{array}{c}\text { Formal } \\
\text { Authority }\end{array}$} & \multicolumn{2}{|c|}{$\begin{array}{c}\text { Personal } \\
\text { Model }\end{array}$} & \multicolumn{2}{|c|}{ Delegator } & \multicolumn{2}{|c|}{ Facilitator } \\
\hline & No & $\%$ & No & $\%$ & No & $\%$ & No & $\%$ & No & $\%$ \\
\hline Low (1-13) & 4 & 5.7 & 0 & 0 & 4 & 5.7 & 4 & 5.7 & 4 & 5.7 \\
\hline Moderate (14-27) & 15 & 21.4 & 40 & 57.1 & 21 & 30 & 36 & 51.4 & 18 & 25.7 \\
\hline High $(28-40)$ & 51 & 72.9 & 30 & 42.9 & 45 & 64.3 & 30 & 42.9 & 48 & 68.6 \\
\hline $\mathrm{X}+$ S.D & \multicolumn{2}{|c|}{$32.357 \pm 5.14$} & \multicolumn{2}{|c|}{$30.057 \pm 4.469$} & \multicolumn{2}{|c|}{$31.429 \pm 5.563$} & \multicolumn{2}{|c|}{$29.871 \pm 5.736$} & \multicolumn{2}{|c|}{$31.614 \pm 6.499$} \\
\hline
\end{tabular}

Table (6): One- way ANOVA of Teaching Styles by Years of Experience of the Study Subjects. $(\mathrm{N}=\mathbf{7 0})$

\begin{tabular}{|c|c|c|c|c|}
\hline \multirow{3}{*}{$\begin{array}{c}\text { Teaching } \\
\text { styles }\end{array}$} & \multicolumn{3}{|c|}{ Years of experience } & \multirow{3}{*}{$\begin{array}{c}\mathbf{P} \\
\text { value }\end{array}$} \\
\hline & $\begin{array}{c}\text { Less than } 5 \\
\text { years }\end{array}$ & $5-10$ years & $\begin{array}{c}\text { More than } 10 \\
\text { years }\end{array}$ & \\
\hline & $X \pm$ S.D & $X \pm$ S.D & $X \pm$ S.D & \\
\hline Expert & $33.714 \pm 4.088$ & $33.667 \pm 2.587$ & $29.455 \pm 7.069$ & $0.005 * *$ \\
\hline $\begin{array}{c}\text { Formal } \\
\text { authority }\end{array}$ & $31.000 \pm 4.171$ & $31.556 \pm 2.679$ & $27.318 \pm 5.339$ & $0.001 * *$ \\
\hline $\begin{array}{c}\text { Personal } \\
\text { model }\end{array}$ & $32.143 \pm 4.151$ & $33.111 \pm 2.562$ & $28.682 \pm 8.067$ & $0.01 *$ \\
\hline Facilitator & $33.000 \pm 3.507$ & $33.444 \pm 2.847$ & $28.046 \pm 9.873$ & $0.006 * *$ \\
\hline Delegator & $31.571 \pm 4.094$ & $30.667 \pm 4.160$ & $27.273 \pm 7.741$ & $0.03 *$ \\
\hline
\end{tabular}

Table (7): One- way ANOVA of Teaching Styles by Academic Qualification of the Study Subjects. (N=70)

\begin{tabular}{|c|c|c|c|c|}
\hline \multirow{3}{*}{ Teaching styles } & \multicolumn{3}{|c|}{$\begin{array}{c}\text { Academic Qualification } \\
\end{array}$} & \multirow{3}{*}{$\begin{array}{c}\mathbf{P} \\
\text { value }\end{array}$} \\
\hline & $\begin{array}{c}\text { Baccalaureate } \\
\text { degree }\end{array}$ & Master degree & Doctorate degree & \\
\hline & $\mathrm{X} \pm$ S.D & $\mathrm{X} \pm$ S.D & X \pm S.D & \\
\hline Expert & $32.600+3.562$ & $34.000+2.533$ & $30.240+7.276$ & $0.02 *$ \\
\hline Formal authority & $29.000+4.766$ & $31.500 \pm 3.159$ & $28.960 \pm 5.248$ & $0.06 \mathrm{NS}$ \\
\hline Personal model & $31.200 \pm 3.5965$ & $32.700 \pm 3.697$ & $30.040 \pm 7.813$ & $0.209 \mathrm{NS}$ \\
\hline Facilitator & $30.800 \pm 3.098$ & $33.600 \pm 2.884$ & $29.720 \pm 9.834$ & $0.07 \mathrm{NS}$ \\
\hline Delegator & $28.600 \pm 2.746$ & $32.000 \pm 3.939$ & $28.080 \pm 7.836$ & $0.02 *$ \\
\hline
\end{tabular}


Educational Philosophy versus Teaching Styles

Table (8): Relationship between Educational Philosophies and Teaching Styles of the Study Subjects

\begin{tabular}{|c|c|c|c|c|c|c|c|}
\hline \multirow{3}{*}{$\begin{array}{l}\text { Educational } \\
\text { Philosophies }\end{array}$} & \multicolumn{5}{|c|}{ Teaching styles } & \multirow{3}{*}{$\begin{array}{c}\mathbf{T} \\
\text { value }\end{array}$} & \multirow{3}{*}{$\begin{array}{c}\mathbf{P} \\
\text { value }\end{array}$} \\
\hline & Expert & $\begin{array}{c}\text { Formal } \\
\text { authority }\end{array}$ & $\begin{array}{c}\text { Personal } \\
\text { model }\end{array}$ & Facilitator & Delegator & & \\
\hline & $\mathrm{X} \pm$ S.D & $X \pm$ S.D & $\mathrm{X} \pm$ S.D & $\mathrm{X} \pm$ S.D & $\mathrm{X} \pm$ S.D & & \\
\hline Liberal & $\begin{array}{c}30.757 \pm \\
4.982\end{array}$ & $\begin{array}{c}28.457 \pm 4.57 \\
0\end{array}$ & $\begin{array}{c}29.828 \pm \\
5.521\end{array}$ & $\begin{array}{c}30.014 \pm \\
6.333\end{array}$ & $\begin{array}{c}28.271 \pm \\
5.612\end{array}$ & 21.906 & $0.001 * *$ \\
\hline Behavioral & $\begin{array}{c}30.843 \pm \\
4.986\end{array}$ & $\begin{array}{c}28.543 \pm \\
4.474\end{array}$ & $\begin{array}{c}29.914 \pm \\
5.469\end{array}$ & $\begin{array}{c}30.100 \pm \\
6.297\end{array}$ & $\begin{array}{c}28.357 \pm \\
5.569\end{array}$ & 18.583 & $0.008 * *$ \\
\hline Progressive & $\begin{array}{c}30.757 \pm \\
4.999\end{array}$ & $\begin{array}{c}28.457 \pm \\
4.523\end{array}$ & $\begin{array}{c}29.828 \pm \\
5.514\end{array}$ & $\begin{array}{c}30.014 \pm \\
6.319\end{array}$ & $\begin{array}{c}28.271 \pm \\
5.589\end{array}$ & 18.896 & $0.005^{* *}$ \\
\hline Humanistic & $\begin{array}{c}30.628 \pm \\
4.996\end{array}$ & $\begin{array}{c}28.328 \pm \\
4.422\end{array}$ & $\begin{array}{c}29.700 \pm \\
5.441\end{array}$ & $\begin{array}{c}29.886 \pm \\
6.294\end{array}$ & $\begin{array}{c}28.143 \pm \\
5.590\end{array}$ & 21.787 & $0.01 *$ \\
\hline Radical & $\begin{array}{c}30.714 \pm 5.03 \\
+6\end{array}$ & $\begin{array}{c}28.414 \pm \\
4.483\end{array}$ & $\begin{array}{c}29.786 \pm 5.50 \\
0\end{array}$ & $\begin{array}{c}29.971 \pm \\
6.343\end{array}$ & $\begin{array}{c}28.229 \pm \\
5.603\end{array}$ & 20.967 & $0.005^{* *}$ \\
\hline
\end{tabular}




\section{References}

1. Floyd D. An exploratory study of the philosophy and teaching styles of Georgia workforce educators and entrepreneurship educators. Doctoral thesis, faculty of Auburn, Alabama University. 2010.

2. Zhang L, Huang J, Zhang L. Preferences in teaching styles among Hong Kong and US university students. International Journal of Psychology, 2005; 39(1):13191331. Available at: wwW.sciencedirect.com.

3. Suissa, J. Teaching and doing philosophy of education: The question of style. Studies in Philosophy \& Education Journal, 2009; 27(3): 185-195.

4. Day M, Amstutz D. Beyond philosophical identification: Examining core values in adult education. Paper presented at the Adult Education Research Conference, San Francisco State University, San Francisco, 2003.

5. Lehman M. Interrupting the reflective practitioner: Unpublished doctoral dissertation, the Ohio State University. 2003

6. Rodrigues K. Do learning styles, learning strategies, and student's preference for educator's teaching philosophy predict student preference for online or in-class courses. Doctoral thesis, Faculty of the
Graduate College, Oklahoma state University.2009.

7. Heimlich J, Norland E. Teaching style. Continuing Education Journal, 2002; 93(1): 17-25.

8. Brown L. Teaching style vs. learning style (Report). Columbus, OH: Center on Education and Training for Employment. 2003. Available at: www.elsevier.com.

9. Zhang F. Preferred teaching styles and modes of thinking among university students in mainland China. Educational Research Journal, 2006; 1(1):95-107. Available at: www.sciencedirect.com.

10. Michael J. Learning and teaching styles in management education: identifying, analyzing, and facilitating. Journal of College Teaching and Learning, 2008; 5 (1): 69-78.

11. Orhun F. Training \& teaching style in accessing a desired classroom discipline at visual art courses. Procedia Social and Behavioral Sciences journal, 2009;6(1):692-696

12. Galbraith M. Adult learning methods: A guide for effective instruction. $3^{\text {rd. }} \mathrm{Ed}$. Malabar, FL: Krieger. 2004.

13. Grasha F, Riechmann R. Teaching style survey. 2006. Available at: http://longleaf.net/teachingstyle.html.

14. West D. An exploratory study of the relationship between the teaching 
Educational Philosophy versus Teaching Styles

philosophies and teaching styles of seminary professors. Doctoral thesis.

Faculty of education. Virginia Commonwealth University.2008.

15. Glenn J. Teaching the net generation. Business education forum Journal, 2000; 54(3):6-14.

16. Zhang F. Do personality traits make a difference in teaching styles among Chinese high school educators? International Journal of Psychology 2007; 43(1):669-679. Available at: www.elsevier.com.

17. Elias J. Merriam S. Philosophical foundations of adult education. $3^{\text {rd }} \mathrm{Ed}$. Malabar, FL: Krieger. 2005.

18. Willson A. Predictors of teaching styles and the adult education philosophies of educators of radiologic technology programs. Unpublished doctoral dissertation, Touro University International. 2006.

19. Amir R, Jelas Z. Teaching and learning styles in higher education institutions. Procedia Social and Behavioral Sciences journal, 2010; 7(3): 680-684.

20. Kulinna P, Cothran D. Physical education teachers' self-reported use and perceptions of various teaching styles. Learning and Instruction Journal, 2003; 13(1): 597-609.

21. Opdenakker M, Damme J. Educator characteristics and teaching styles as effectiveness enhancing factors of classroom practice. Teaching and Teacher Education Journal, 2006; 22 (1): 1-21. Available at: www.elsevier.com.

22. Rossi C. A Study Of community college learner-centered teaching styles and students' motivation to learn. Doctoral thesis, Faculty of the Graduate School Saint Louis University. 2009.

23. Naimie Z, Siraj S, Piaw C, Shagholi R, Abuzaid R. Teaching styles/learning styles match and mismatch revisited Procedia Social and Behavioral Sciences Journal, 2010;2(1):349-353. Available at: www.sciencedirect.com.

24. Andrews T. Teaching mode efficiency and learning preferences of first year nursing students. Nurse Education Today Journal, 2009; 29(1): 24-32. Available at: www.sciencedirect.com

25. Sawatzky J. Teaching excellence in nursing education: a caring framework. Journal of Professional Nursing, 2009; 25(5): 260-266.

26. O'Brien M. Teaching style and teaching philosophy of rehabilitation educators. Unpublished doctoral dissertation, Oklahoma State University, Stillwater. 2001. 